\section{Performance and immune response of 1 to 21-day-old broilers fed diets supplemented with organic zinc}

\author{
Desempenho e resposta imune de frangos de corte de 1 a 21 dias \\ alimentados com dietas suplementadas com zinco orgânico
}

\author{
Sandra Regina Gomes da Silva'* (D) , João Batista Lopes² (1), Daniel Medeiros de Noronha Albuquerque ${ }^{3}$ (1), \\ Elvânia Maria da Silva Costa Moreira ${ }^{\text {(D) }}$, Daniela Cristina Pereira Lima ${ }^{5}$ (D) \& Mabell Nery Ribeiro ${ }^{6}$ (D) \\ 'Veterinarian, DSc. Departamento de Zootecnia, Universidade Federal do Piauí - UFPI, Campus Petrônio Portela, Teresina, PI, Brasil \\ ${ }^{2}$ Agronomist, DSc. Universidade Federal do Piauí - UFPI, Teresina, PI, Brasil \\ ${ }^{3}$ Veterinarian, DSc. Instituto Federal de Educação, Ciência e Tecnologia do Piauí - IFPI, Campo Maior, PI, Brasil \\ ${ }^{4}$ Agronomist, DSc. Curso de Graduação em Zootecnia - Campus Professora Cinobelina Elvas, Universidade Federal do Piauí - \\ UFPI, Bom Jesus, PI, Brasil \\ ${ }^{5}$ Veterinarian, DSc. Secretaria de Educação - SEDUC, Teresina, PI, Brasil \\ ${ }^{6}$ Veterinarian, DSc. Instituto Federal de Educação, Ciência e Tecnologia do Piauí - IFPI, Uruçuí, PI, Brasil
}

\begin{abstract}
The objective of this study was to evaluate the effect of organic zinc supplementation in broiler diets from 1 to 21 days on performance and immune response. The experimental design was completely randomized, with four treatments and five replications. The treatments consisted of supplementation of the diet with organic zinc at levels $30,60,90 \mathrm{mg} / \mathrm{kg}$ and one more control treatment. The guarantee level of the organic zinc (carb-amino-phosph-cellate) used was 100,000 mg/kg. In the pre-starter phase, 1 to 7 days, the treatments quadratically influenced the feed intake $(\mathrm{P}=0.02)$ according to the equation: $\mathrm{y}=$ $-6 \mathrm{E}-06 \mathrm{x}^{2}+0.0007 \mathrm{x}+0.1273\left(\mathrm{R}^{2}=0.93\right)$, where the highest consumption level was obtained with $60 \mathrm{mg}$ zinc/kg and weight gain with $60 \mathrm{mg}$ zinc/kg. They quadratically influenced carcass yield and pancreas weight, providing higher values at 47.33 and $75 \mathrm{mg} / \mathrm{kg}$, respectively. Relative heart weight was positively influenced by the treatments. It was concluded that the supplementation of the diet with organic zinc has an effect on the performance, influences the carcass yield, the circulatory and endocrine system of broilers.
\end{abstract}

Keywords: circulatory system, digestive organs, lymphoid organs, mineral.

\section{Resumo}

Objetivou-se avaliar o efeito da suplementação com zinco orgânico em dietas de frangos de corte, por 1a 21 dias, sobre o desempenho e resposta imune. O delineamento experimental foi o inteiramente casualizado, com quatro tratamentos e cinco repetições. Os tratamentos consistiram na suplementação da ração com zinco orgânico nos níveis 30,60, 90 mg/kg e mais um tratamento controle. O nível de garantia do zinco orgânico (carboaminofosfoquelatado) utilizado foi $100.000 \mathrm{mg} / \mathrm{kg}$. Na fase pré-inical, 1 a 7 dias, os tratamentos influenciaram de forma quadrática o consumo de ração $(\mathrm{P}=0,02)$ de acordo com a equação: $\mathrm{y}=-6 \mathrm{E}-06 \mathrm{x}^{2}+0,0007 \mathrm{x}+0,1273\left(\mathrm{R}^{2}=0,93\right)$, em que o nível de maior consumo foi obtido com 60 mg de zinco/ $\mathrm{kg}$ e de ganho de peso com $60 \mathrm{mg}$ zinco $/ \mathrm{kg}$. Influenciaram de forma quadrática o rendimento de carcaça e o peso do pâncreas, propiciando maiores valores nos níveis de 47,33 e $75 \mathrm{mg} / \mathrm{kg}$, respectivamente. $\mathrm{O}$ peso relativo do coração foi influenciado de forma linear positiva pelos tratamentos. Conclui-se que a suplementação da ração com zinco orgânico tem efeito sobre o desempenho, influencia no rendimento de carcaça, no sistema circulatório e endócrino dos frangos de corte.

Palavras-chave: sistema circulatório, órgãos digestivos, órgãos linfoides, mineral.

\section{Introduction}

Nowadays, nutritionists are concerned not only with improving productivity, but also with its synchronization with the welfare and immune capacity of animals. Thus, micronutrients such as zinc are becoming increasingly important, which supplementation may be useful for enhancing the performance of birds, acting at the level of the immune system, increasing the resistance of these animals to invasive organisms, and is also important for animal welfare \section{BJ M Brazilian Journal of Veterinary Medicine

How to cite: Silva, S. R. G., Lopes J. B., Albuquerque, D. M. N., Moreira, E. M. S. C., Lima, D. C. P., \& Ribeiro, M. N. (2020). Performance and immune response of 1 to 21-day-old broilers fed diets supplemented with organic zinc. Brazilian Journal of Veterinary Medicine, 42, e101120. https://doi. org/10.29374/2527-2179.bjvm101120

Financial support: Fundação de Amparo à Pesquisa do Estado Piauí - FAPEPI.

Conflict of interests: No conflict of interests declared concerning the publication of this article.

Received: November 20, 2018. Accepted: July 07, 2019.

The study was carried out at Departamento de Zootecnia - DZO, Universidade Federal do Piauí - UFPI, Teresina, PI, Brasil

\section{*Correspondence}

Sandra Regina Gomes da Silva

Departamento de Zootecnia, Universidade Federal do Piauí - UFPI

Campus Ministro Petronio Portella CEP 64049-550 - Teresina (PI), Brasil E-mail: sandravet2006@hotmail.com 
Micro-minerals such as zinc (Zn), copper ( $\mathrm{Cu}$ ), iron (Fe), manganese (Mn), molybdenum (Mo), boron (B) and chlorine (Cl) are essential for the physiological activity of animals even though they participate in diets in small quantities.

Dietary supplementation with organic zinc is a strategy that can benefit bird performance (Salim et al., 2008) and one of its main functions concerns antioxidant action, as it is related to the ability to prevent radical formation (Sunder et al., 2008) and produces antioxidant responses in broilers (Rao et al., 2016).

Yalçinkaya et al. (2012), Kakhkia et al. (2016), point out the dietary supplementation of zinc broilers as a way to improve their immune response, improving their performance under stressful conditions. However, its deficiency can alter crest compliance, cause pododermatitis and even have negative effects on carcass quality (Bao et al., 2010).

Salim et al. (2011) found that dietary supplementation with zinc in organic form did not affect body weight gain, feed intake, feed:gain ratio and viability of male and female broilers, Salabi et al. (2011) observed that the level of $90 \mathrm{mg} / \mathrm{kg}$ of organic zinc in the diet provided higher feed intake and weight gain, which demonstrates the different results found in experimentation with this micromineral.

Thus, the objective of this study was to evaluate the effect of zinc supplementation on organic form in broiler diets from 1 to 21 days of age on performance, carcass yield, relative and absolute weight of lymphoid and digestive organs and heart and percentage of bursal cortex.

\section{Materials and methods}

The research was developed at the Department of Animal Science of the Center of Agrarian Sciences of the Universidade Federal do Piauí. Experiment approved by the Animal Experiment Ethics Committee of the Federal University Piauí CEEA/UFPI, under no. 087/12.

A total of 400 Ross 308 chicks were used, from one to 21 days old, with a mean initial weight of $39 \pm 1.2 \mathrm{~g}$, half of each sex. The experimental design was completely randomized, with four treatments and five replications, twenty birds per experimental unit. The treatments consisted of the supplementation of the basal diet with organic zinc (30; 60; $90 \mathrm{mg}$ of zinc/kg), besides a control treatment. The guarantee level of the organic zinc (carb-amino-phosph-cellate) used was $100,000 \mathrm{mg} / \mathrm{kg}$.

Experimental diets (Table 1) were isonutritive and formulated to meet bird demands, according to Rostagno et al. (2011). The test ingredient was added in place of the inert material.

The birds were housed in a ceramic tile roofed shed, fitted with a curtain around to control drafts, with smooth wire mesh dividers and fans, totaling 20 boxes, each box of approximately $2.8 \mathrm{~m}^{2}$.

Throughout the experimental period the birds were subjected to continuous lighting program (24 hours of natural + artificial light), using 60 watt incandescent lamps. The management of birds throughout the experimental period followed the recommendations proposed for the Ross 308 strain.

Black globe temperature, wet bulb temperature, dry bulb temperature and humidity were measured daily (Table 2 ). The maximum and minimum temperatures were recorded only in the morning, and then the thermometer was reset. These data were then converted to globe temperature and humidity index (ITGU) as advocated by Buffigton et al. (1981), according to the following formula: ITGU $=0.72$ (Tbu + Tgn) +40.6 ; where: $\mathrm{Tbu}=$ Wet bulb temperature in ${ }^{\circ} \mathrm{C}$; Tgn = Black globe temperature in ${ }^{\circ} \mathrm{C}$.

Birds were weighed at the beginning and end of each experimental phase for performance evaluation. On day 21 , two birds with weight closer to the boxing average $( \pm 10 \%)$ were selected by repetition totaling 10 birds per treatment. After 12 hours of fasting, they were slaughtered to evaluate carcass parameters and lymphoid and digestive organs. The cloacal pocket were destined to the Animal Pathology Laboratory, being fixed in $10 \%$ neutral buffered formalin, dehydrated in successive passages in ethyl alcohol at increasing concentrations, xylol diaphanized, infiltrated and paraffin embedded. Then, the pouches were submitted to microtomy, obtaining histological sections with a thickness of $5 \mu \mathrm{m}$, which were stained with hematoxylin-eosin. 
Table 1. Composition of experimental diets for broilers in the pre-starter, 1 to 7 days and initial, from 8 to 21 days old.

\begin{tabular}{lcc}
\hline \multicolumn{1}{c}{ Ingredients } & Growth (1-7 days) & Final (8-21 days) \\
\hline Corn & 51.963 & 55.364 \\
Soybean meal 48\% & 39.167 & 35.585 \\
Vegetable oil & 3.407 & 4.095 \\
Dicalcium phosphate & 1.908 & 1.537 \\
Calcitic limestone & 0.910 & 0.935 \\
NaCl & 0.361 & 0.361 \\
L-Lysine - HCL (79\%) & 0.300 & 0.230 \\
DL-methionine (99\%) & 0.234 & 0.193 \\
Mineral and Vitamin Premix & $0.400^{1}$ & $0.400^{2}$ \\
Kaolin (Inert Material) & 1.350 & 1.300 \\
TOTAL & 100 & 100 \\
Nutritional Composition Analysis & & \\
Crude Protein (\%) & 22.20 & 0.30 .80 \\
ME (kcal/kg) & 2960 & 3050 \\
Digestible Lysine (\%) & 1.342 & 1.200 \\
Digestible methionine (\%) & 0.523 & 0.468 \\
Digestible threonine (\%) & 0.755 & 0.762 \\
Digestible Tryptophan (\%) & 0.253 & 0.234 \\
Calcium (\%) & 0.920 & 0.161 \\
Available match (\%) & 0.162 & \\
Sodium (\%) & & \\
\hline
\end{tabular}

'Guarantee levels per kg of product: folic acid: 199.00 mg; pantothenic acid: 3,119.00 mg; biotin: 10.00 mg; chloro hydroxyquinoline: 7,500.00 mg; copper: 1,996.00 mg; choline: 80.71 g; iron: 11.25 g; iodine: $187.00 \mathrm{mg}$; manganese: $18.74 \mathrm{~g}$; niacin: 8,399.00 mg; nicarbazine: 25.00 g; selenium: 75.00 mg; Vitamin A: 1,680,000 IU; vitamin B1: 436.50 mg; vitamin B12: 2,400.00 mcg; vitamin B2: 1,200.00 mg; vitamin B6: $624.00 \mathrm{mg}$; vitamin D3: 400,000.00 IU; vitamin E: 3,500.00 IU; vitamin K3: $360.00 \mathrm{mg}$; zinc: 17.50 g; ${ }^{2}$ Guarantee levels per kg of product: folic acid: 200.00 mg; pantothenic acid: 3,120.00 mg; biotin: 10.00 mg; chloro hydroxyquinoline: 7,500.00 mg; copper: 1,997.00 mg; choline: 78.10 g; iron: 11.25 g; iodine: 187.47 mg; manganese: 18.74 g; monensin: 25.00 g; niacin: 8,400.00 mg; selenium: 75.00 mg; Vitamin A: 1,680,000 IU; vitamin B1 436.50 mg; vitamin B12:2,400.00 mcg; vitamin B2: 1,200.00 mg; Vitamin B6: 624.00 mg; vitamin D3: 400,000.00 IU; vitamin E:3,500.00 IU; vitamin K3: 360.00 mg; zinc: 17.50 g. ME: Energia Metabolizavel; $\mathrm{HCl}$ : acido cloridrico DL: Não encontramos essa sigla ao longo do manuscrito.

Table 2. Mean maximum and minimum temperature, relative air humidity and Index of Globe temperature and humidity (ITGU) inside the house during the experimental period.

\begin{tabular}{|c|c|c|c|c|c|}
\hline \multirow{2}{*}{$\begin{array}{l}\text { Period } \\
\text { (days) }\end{array}$} & \multicolumn{2}{|c|}{ Temperature ${ }^{\circ} \mathrm{C}$} & \multirow{2}{*}{$\begin{array}{c}\text { Relative } \\
\text { humidity (\%) }\end{array}$} & \multicolumn{2}{|c|}{ ITGU } \\
\hline & Maximum & Minimum & & Morning & Afternoon \\
\hline O1 to 07 & $31.14 \pm 1.34$ & $25.88 \pm 0.70$ & $76.97 \pm 3.66$ & $78.20 \pm 0.68$ & $82.46 \pm 1.20$ \\
\hline 08 to 14 & $30.37 \pm 0.79$ & $25.57 \pm 1.27$ & $82.07 \pm 4.55$ & $78.57 \pm 0.73$ & $82.29 \pm 1.55$ \\
\hline 15 to 21 & $30.33 \pm 1.86$ & $25.25 \pm 0.41$ & $78.78 \pm 7.69$ & $78.42 \pm 0.87$ & $82.30 \pm 0.66$ \\
\hline
\end{tabular}

The percentage of bursal lymphoid follicle cortex was determined by a computerized image analyzer (Leica Qwin D-1000, version 4.1, Cambridge, UK) under 100X magnification using 10 complete bursal follicles.

The breeding viability (CV) was determined according to Stringhini et al. (2006): CV (\%) = [total number of birds - (dead birds + discards) / total number of birds] x 100 and the productive efficiency index (IEP) by the formula: IEP = (mean GP ( $\mathrm{g}) \mathrm{x}$ VC) / CA $\mathrm{x}$ days housed) $\mathrm{x} 10$; where: mean $\mathrm{GP}$ = average weight gain; $\mathrm{CV}$ = breeding viability and CA = feed:gain ratio. 
The carcass yield and the relative weight of the viscera were calculated in relation to the weight of the fasting bird before slaughter and the yield of cuts in relation to the weight of the warm carcass.

Data were subjected to analysis of variance and regression according to GLM procedures of the Statistical Analysis System (SAS).

\section{Results and discussion}

In the pre-starter phase, 1 to 7 days old, the performance variables, feed:gain ratio and productive efficiency index did not suffer treatment effects as observed in Table 3. However, the levels of supplemental organic zinc quadratically influenced the intake. $(\mathrm{P}=0.02)$ according to the equation: $\mathrm{y}=-6 \mathrm{E}-06 \mathrm{x}^{2}+0.0007 \mathrm{x}+0.1273\left(\mathrm{R}^{2}=0.93\right)$, where the highest consumption level was obtained with $60 \mathrm{mg}$ of zinc/kg (Table 3). These results differ from those found by Namazu et al. (2008) that supplementing the diet with organic zinc, in the pre-initial phase did not observe statistical differences in the performance of these animals.

Creativity viability in the pre-starter phase was influenced $(\mathrm{P}=0.03)$ by dietary zinc levels according to the equation $\mathrm{y}=0.0011 \mathrm{x}^{2}-0.1 \mathrm{x}+100, \mathrm{R}^{2}=1$, where the worst Viability was achieved with $30 \mathrm{mg}$ of supplemental organic zinc/kg of feed. Similar results were observed by Ismail et al.

Table 3. Performance of broiler chickens from 1 to 7 and from 1 to 21 days old, fed with organic zinc levels CR feed intake; GP- weight gain; CA- feed:gain ratio; CV-creative viability; IEP- productive efficiency index ${ }^{1} \mathrm{~L}$ - linear effect, Q - quadratic effect.

\begin{tabular}{|c|c|c|c|c|c|c|c|}
\hline & \multicolumn{4}{|c|}{ Levels of zinc (mg/kg) } & \multirow{2}{*}{ CV (\%) } & \multicolumn{2}{|c|}{ Value $\mathrm{P}^{1}$} \\
\hline & 0 & 30 & 60 & 90 & & $\mathbf{L}$ & Q \\
\hline \multicolumn{8}{|c|}{1 to 7 days } \\
\hline \multirow[t]{2}{*}{ CR (g/bird) } & 0.128 & 0.138 & 0.145 & 0.134 & 7.29 & 0.24 & 0.02 \\
\hline & \pm 0.005 & \pm 0.013 & \pm 0.005 & \pm 0.012 & & & \\
\hline \multirow[t]{2}{*}{ GP (g/bird) } & 0.109 & 0.111 & 0.114 & 0.108 & 3.99 & 0.72 & 0.06 \\
\hline & \pm 0.004 & \pm 0.005 & \pm 0.004 & \pm 0.002 & & & \\
\hline \multirow[t]{2}{*}{ CA (g/g) } & 1.17 & 1.25 & 1.27 & 1.23 & 7.48 & 0.33 & 0.18 \\
\hline & \pm 0.03 & \pm 0.13 & \pm 0.07 & \pm 0.09 & & & \\
\hline \multirow[t]{2}{*}{ VC (\%) } & 100 & 98 & 98 & 100 & 1.95 & 1.00 & 0.03 \\
\hline & \pm 0.0 & \pm 2.7 & \pm 2.7 & \pm 0.0 & & & \\
\hline \multirow[t]{2}{*}{ IEP } & 132.39 & 125.30 & 126.80 & 126.63 & 9.53 & 0.52 & 0.53 \\
\hline & \pm 8.5 & \pm 14.9 & \pm 15.1 & \pm 8.1 & & & \\
\hline \multicolumn{8}{|c|}{1 to 21 days } \\
\hline \multirow[t]{2}{*}{ CR (g/bird) } & 1.074 & 1.065 & 1.103 & 1.082 & 4.63 & 0.55 & 0.79 \\
\hline & \pm 0.03 & \pm 0.03 & \pm 0.05 & 0.06 & & & \\
\hline \multirow[t]{2}{*}{ GP (g/bird) } & 0.681 & 0.677 & 0.692 & 0.671 & 2.62 & 0.70 & 0.31 \\
\hline & \pm 0.01 & \pm 0.01 & \pm 0.02 & \pm 0.02 & & & \\
\hline \multirow[t]{2}{*}{$\mathrm{CA}(\mathrm{g} / \mathrm{g})$} & 1.57 & 1.57 & 1.59 & 1.61 & 3.18 & 0.25 & 0.63 \\
\hline & \pm 0.03 & \pm 0.04 & \pm 0.05 & \pm 0.05 & & & \\
\hline \multirow[t]{2}{*}{ VC (\%) } & 99 & 92 & 99 & 100 & 2.18 & 0.35 & 0.30 \\
\hline & \pm 2.2 & \pm 2.7 & \pm 2.2 & \pm 0.0 & & & \\
\hline \multirow[t]{2}{*}{ IEP } & 213.8 & 211.18 & 215.28 & 208.64 & 4.57 & 0.56 & 0.65 \\
\hline & \pm 9.7 & \pm 6.9 & \pm 14.1 & \pm 5.1 & & & \\
\hline
\end{tabular}

Parameter: FI - feed intake; WG - weight gain; FC - feed conversion; PV - production viability; PEI - productive efficiency index; ${ }^{2} \mathrm{~L}$ - linear effect, Q - quadratic effect. P: probabilidade; VC: Viabilidade criatoria. 
(2013) in a study with broilers raised at high temperature $\left(39^{\circ} \mathrm{C}\right)$, in the phase from 1 to 14 days of age, in which there was a reduction in mortality of $2 \%$ of birds compared to non-supplemented animals.

In the period from 1 to 21 days, the levels of supplemental organic zinc did not influence ( $P>0.05$ ) feed intake, weight gain, feed:gain ratio, productive efficiency index and breeding viability. Similar results were found by Rao et al. (2016) working under similar temperature conditions and using organic zinc (20-40 mg/kg) in the 1 to 21 day phase. Recent research (Kakhkia et al., 2016) indicates that the use of organic zinc in the diet had no effect on performance in animals up to 35 days old using higher zinc levels (40-80 mg/kg).

In the literature it is possible to find positive results of zinc supplementation on broiler performance at this stage (Salabi et al., 2011). These contradictory results may be, according to Leeson \& Summers (2009), due to the different bioavailability of dietary zinc samples.

The treatments quadratically influenced ( $\mathrm{P}=0.05$ ) the carcass yield of the animals supplemented with organic zinc (Figure 1). The highest carcass yield was obtained with $60 \mathrm{mg}$ organic zinc/kg feed. It can be inferred that although the performance of the animals in the pre-initial phase,

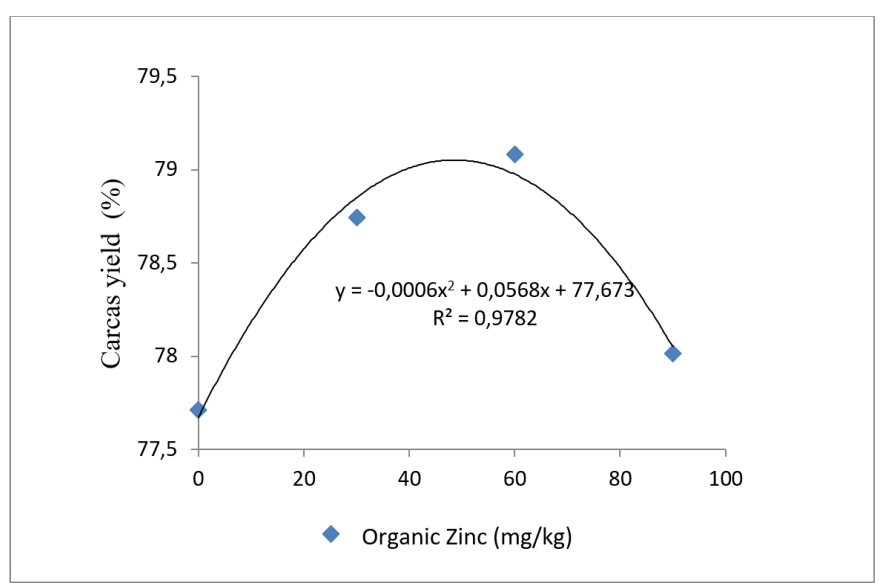

Figure 1. Carcass yield of 21-day-old broilers fed organic zinc levels.

1 to 7 days, did not provide difference in the performance of the animals, after 21 days, there was interference in the carcass yield.

Treatments did not influence liver, gizzard and intestine weights as observed in Table 4, but quadratically influence $(\mathrm{P}=0.02)$ the relative and absolute weight of the pancreas, according to the respective equations $\mathrm{y}=2 \mathrm{E}-05 \mathrm{x}^{2}-0.0015 \mathrm{x}+0.3686\left(\mathrm{R}^{2}=0.50\right) ; \mathrm{y}=-0.0668 \mathrm{x}+2.56\left(\mathrm{R}^{2}=0.3\right)$, where the level of organic zinc that reached the highest relative organ weight was $90 \mathrm{mg} / \mathrm{kg}$. Thus, it may be suggested that zinc has a protective role in pancreatic tissue against oxidative damage, and may help this gland to function properly by increasing the secretion of digestive enzymes and thereby improving nutrient digestibility and bird performance (Tawfeek et al., 2014).

The influence of organic zinc levels on the relative heart weight linearly $(\mathrm{P}=0.02)$ was observed, according to the equation $\mathrm{y}=0.0013 \mathrm{x}+0.6444\left(\mathrm{R}^{2}=0.84\right)$. Importantly, the cardiovascular system operates in acclimatization of animals during heat exposure of birds, where expansion of plasma volume is an important mechanism of adaptation with increased blood volume, increased hematocrit/hemoglobin ratio and often weight variation in the heart. Changes in the cardiovascular system may also occur to accommodate the required oxygen (Yahav, 1999).

Thus, with these results, it can be inferred that the increase in the level of organic zinc in the diet of up to $90 \mathrm{mg} / \mathrm{kg}$, increases the relative weight of the heart, and can probably improve its potential against the deleterious effects of stress, influencing positively on animal welfare in the studied phase. 
Table 4. Gut weight of 21-day-old broilers fed organic zinc levels.

\begin{tabular}{|c|c|c|c|c|c|c|c|}
\hline \multirow{2}{*}{ Víscera } & \multicolumn{4}{|c|}{ Levels of Zinc (mg/Kg) } & \multirow{2}{*}{$\begin{array}{l}\text { CV } \\
\text { (\%) }\end{array}$} & \multicolumn{2}{|c|}{ Value of $P^{1}$} \\
\hline & 0 & 30 & 60 & 90 & & $\mathbf{L}$ & $\mathbf{Q}$ \\
\hline Liver g & $16.3 \pm 0.93$ & $17.9 \pm 2.51$ & $17.7 \pm 1.29$ & $17.4 \pm 2.32$ & 10.6 & 0.46 & 0.29 \\
\hline Liver \% & $2.3 \pm 0.10$ & $2.6 \pm 0.34$ & $2.6 \pm 0.21$ & $2.6 \pm 0.21$ & 9.6 & 0.10 & 0.28 \\
\hline Gizzard g & $23.4 \pm 2.23$ & $22.0 \pm 1.42$ & $23.6 \pm 2.61$ & $21.2 \pm 2.77$ & 10.3 & 0.32 & 0.65 \\
\hline Gizzard \% & $3.3 \pm 0.25$ & $3.1 \pm 0.17$ & $3.5 \pm 0.39$ & $3.2 \pm 0.36$ & 9.3 & 0.79 & 0.61 \\
\hline Intestine g & $35.9 \pm 4.19$ & $34.7 \pm 2.09$ & $35.0 \pm 3.19$ & $34.3 \pm 1.81$ & 8.5 & 0.45 & 0.86 \\
\hline Intestine \% & $5.1 \pm 0.48$ & $5.00 \pm 0.30$ & $5.17 \pm 0.61$ & $5.14 \pm 0.38$ & 9.0 & 0.79 & 0.84 \\
\hline Heart g & $4.5 \pm 0.46$ & $4.6 \pm 0.49$ & $5.1 \pm 0.54$ & $5.0 \pm 0.86$ & 12.3 & 0.13 & 0.63 \\
\hline Heart \% & $0.64 \pm 0.05$ & $0.67 \pm 0.06$ & $0.75 \pm 0.06$ & $0.75 \pm 0.11$ & 10.9 & 0.02 & 0.64 \\
\hline Pancreas g & $2.5 \pm 0.18$ & $2.4 \pm 0.38$ & $2.2 \pm 0.19$ & $2.4 \pm 0.17$ & 6.9 & 0.14 & 0.02 \\
\hline Pancreas \% & $0.36 \pm 0.03$ & $0.36 \pm 0.06$ & $0.32 \pm 0.03$ & $0.37 \pm 0.02$ & 7.1 & 0.72 & 0.02 \\
\hline
\end{tabular}

"L - linear effect, Q - quadratic effect, CV - Coeficiente de variacao, P - probabilidade.

Table 5. Lymphoid organ weight, cloacal pocket diameter, and percentage of bursal cortex of broilers at 21 days, fed with increasing levels of organic zinc.

\begin{tabular}{|c|c|c|c|c|c|c|c|}
\hline & \multicolumn{4}{|c|}{ Levels of Zinc (mg/Kg) } & \multirow{2}{*}{ CV (\%) } & \multicolumn{2}{|c|}{ Value de $P$} \\
\hline & 0 & 30 & 60 & 90 & & $\mathbf{L}$ & $\mathbf{Q}$ \\
\hline cloacal pocket (g) & $2.1 \pm 0.33$ & $2.1 \pm 0.28$ & $2.0 \pm 0.14$ & $1.9 \pm 0.52$ & 13.0 & 0.19 & 0.99 \\
\hline cloacal pocket (\%) & $0.30 \pm 0.05$ & $0.30 \pm 0.04$ & $0.29 \pm 0.02$ & $0.29 \pm 0.03$ & 13.0 & 0.48 & 0.96 \\
\hline cloacal pocket cm & $1.42 \pm 0.10$ & $1.64 \pm 0.14$ & $1.57 \pm 0.13$ & $1.61 \pm 0.19$ & 9.5 & 0.11 & 0.19 \\
\hline Thymus g & $2.8 \pm 1.14$ & $3.5 \pm 0.60$ & $3.3 \pm 0.73$ & $3.4 \pm 0.38$ & 23.1 & 0.34 & 0.33 \\
\hline Thymus & $0.39 \pm 0.16$ & $0.51 \pm 0.08$ & $0.48 \pm 0.10$ & $0.51 \pm 0.06$ & 23.0 & 0.20 & 0.37 \\
\hline Spleeng & $0.66 \pm 0.11$ & $0.58 \pm 0.13$ & $0.55 \pm 0.06$ & $0.58 \pm 0.04$ & 15.9 & 0.14 & 0.20 \\
\hline Spleen \% & $0.09 \pm 0.02$ & $0.08 \pm 0.02$ & $0.08 \pm 0.01$ & $0.08 \pm 0.00$ & 16.5 & 0.36 & 0.21 \\
\hline Cortex \% & $40.96 \pm 3.6$ & $37.42 \pm 3.0$ & $39.42 \pm 2.4$ & $39.33 \pm 3.5$ & 8.8 & 0.65 & 0.24 \\
\hline
\end{tabular}

'L - linear effect, Q - quadratic effect, CV - coeficiente de variacao, P - Probabilidade.

The biometrics of the lymphoid organs (thymus, spleen, cloacal sac) was not influenced by the dietary organic zinc levels (Table 5). Similar results were found by Lopes et al. (2015) who supplemented the diet of birds from 1 to 21 days to the level of $120 \mathrm{mg} / \mathrm{kg}$ of organic zinc. According to Feng et al. (2010) The lymphoid organs such as thymus, spleen and cloacal sac have their weights increased linearly with the increase of dietary zinc. This observation has been confirmed in several papers (Salabi et al., 2011; Yalçinkaya et al., 2012; Kakhkia et al., 2016). Thus this parameter is also a controversial point that can be partly explained by environmental differences, the source, level and availability of supplemented zinc in the diet, animal lineage and treatment time to which they are submitted, degree of immunity and unhealthy content of the environment.

The percentage of birds' bursal cortex at 21 days of age was not influenced by organic zinc levels, confirming observations by Muniz et al. (2006) about birds in thermal comfort have a higher percentage of parenchyma and better immune response conditions.

\section{Conclusions}

Organic zinc supplementation in the 1- to 7-day phase has a positive effect on animal performance. At 21 days of age, birds fed $60 \mathrm{mg}$ of organic zinc/kg of feed provide higher carcass yield and with $90 \mathrm{mg}$ of organic zinc/kg of feed there is a higher relative weight of the pancreas and heart. 


\section{Acknowledgements}

To Fundação de Amparo à Pesquisa do Estado Piauí - FAPEPI for funding the research.

\section{References}

Bao, Y. M., Choct, M., Iji, P. A., \& Bruerton, K. (2010). Trace mineral interactions in broiler chicken diets. British Poultry Science, 51(1), 109-117. http://dx.doi.org/10.1080/00071660903571904. PMid:20390575.

Buffigton, D. E., Collazo-Arocho, A., Canton, G. H., \& Pitt, D. (1981). Black globe-humidity índex (BGHI) as comfort equation for dairy cows. Transactions of the ASAE, 24(3), 711-714.

Feng, J., Ma, W. Q., Niu, H. H., Wu, X. M., Wang, Y., \& Feng, J. (2010). Effects of zinc glycine chelate on growth, hematological and immunological characteristics in broilers. Biological Trace Element Research, 133(2), 203211. http://dx.doi.org/10.1007/s12011-009-8431-9. PMid:19551351.

Ismail, I. B., Al-Busadah, K. A., \& El-Bahr, S. M. (2013). Oxidative stress biomarkers and biochemical profile in broilers chichen fed zinc bactracin and ascorbic acid under hot climate. American Journal of Biochemistry and Molecular Biology, 3(2), 202-214. http://dx.doi.org/10.3923/ajbmb.2013.202.214.

Kakhkia, R. A. M., Bakhshalinejada, R., \& Shafieeb, M. (2016). Effect of dietary zinc and $\alpha$-tocopheryl acetate on broiler performance, immune responses, antioxidant enzyme activities, minerals and vitamin concentration in blood and tissues of broilers. Animal Feed Science and Technology, 221(221), 12-26.

Leeson, S., \& Summers, J. D. (2009). Commercial poultry nutrition (591p.). Nottingham: Nottingham University Press.

Lopes, J. C. O., Figueiredo, A. V., Lopes, J. B., Lima, D. C. P., Ribeiro, M. N., \& Lima, V. B. S. (2015). Zinco e vitamina Eem dietas para frangos de corte criados em estresse calórico. Revista Brasileira de Saúdee Produção Animal, 16(2), 350-364. http://dx.doi.org/10.1590/S1519-99402015000200010.

Muniz, E. C., Fascina, V. B., Pires, P. P., Carrijo, A. S., \& Guimarães, E. B. (2006). Histomorphology of bursa of Fabricius: effects of stock densities on commercial broilers. Revista Brasileira de Ciência Avícola, 8(4), 217-220. http://dx.doi.org/10.1590/S1516-635X2006000400003.

Namazu, L. B., Kobashigawa, E., Albuquerque, R., Schammass, E. A., Takeara, P., \& Trindade Neto, M. A. (2008). Lisina digestível e zinco quelado para frangos de corte machos: desempenho e retenção de nitrogênio na fase pré-inicial. Revista Brasileira de Zootecnia,37(9), 1634-1640. http://dx.doi.org/10.1590/S1516-35982008000900016.

Rao, S. V. R., Prakash, B., Raju, M. V. L., Panda, A. K., Kamuri, R. K., \& Reddy, P. K. (2016). Effect of supplementing organic forms of zinc, selenium and chromium on Performance, anti-oxidant and immune responses in broiler chicken reared in tropical summer. Biological Trace Element Research, 172(2), 511-520.

Rostagno, H. S., Albino, L. F. T., Donzele, J. L., Gomes, P. C., Oliveira, R. F., Lopes, D. C., Ferreira, A. S., Barreto, S. L. T., \& Euclides, R. F. (2011). Tabelas brasileiras para aves e suínos: composição de alimentos e exigências nutricionais (252 p.). Viçosa: Imprensa Universitária.

Salabi, F., Boujarpoor, M., Fayazi, J., Salari, S., \& Nazari, M. (2011). Effects of different levels of zinc on the performance and carcass characteristics of broiler rearedunder heat stress condition. Journal of Animal and Veterinary Advances, 10(10), 1332-1335. http://dx.doi.org/10.3923/javaa.2011.1332.1335.

Salim, H. M., Jo, C., \& Lee, B. D. (2008). Zinc in broiler feeding and nutrition. Avian Biology Research, 1(1), 5-18. http://dx.doi.org/10.3184/175815508X334578.

Salim, H. M., Lee, H. R., Jo, C., Lee, S. K., \& Lee, B. D. (2011). Supplementation of graded levels of organic Zn to the diets of female broilers: effect on performance and carcass quality. British Poultry Science, 52(5), 606-612. http://dx.doi.org/10.1080/00071668.2011.616485. PMid:22029788.

Stringhini, J. H., Andrade, M. L., Andrade, L., Xavier, S. A. G., Café, M. B., \& Leandro, N. S. M. (2006). Desempenho, balanço e retenção de nutrientes e biometria dos órgãos digestivos de frangos de corte alimentados com diferentes níveis de proteína na ração pré-inicial. Revista Brasileira de Zootecnia, 35(6), 2350-2358. http:// dx.doi.org/10.1590/S1516-35982006000800022.

Sunder, G. S., Panda, A., Gopinath, N., Rao, S. R., Raju, M., Reddy, M., \& Kumar, C. V. (2008). Effects of higher levels of zinc supplementation on performance, mineral availability, and immune competence in broiler chickens. Journal of Applied Poultry Research, 17(1), 79-86. http://dx.doi.org/10.3382/japr.2007-00029.

Tawfeek, S. S., Hassanink, K. M. A., \& Youssef, I. (2014). The effect of dietary supplementation of some antioxidants on performance, oxidative stress, and blood parameters in broilers under natural summer conditions. Journal World's Poultry Research, 4(1), 10-19.

Yahav, S. (1999). The effect of constant and diurnal cyclic temperatures on performane an blood system of young turkeys. Journal of Thermal Biology, 24(1), 71-78. http://dx.doi.org/10.1016/S0306-4565(98)00042-4.

Yalçinkaya, I., Çinar, M., \& Yildirim, E., Erat, S., Başalan, M., \& Güngör, T. (2012). The effect of prebiotic and organic zinc alone and in combination in broiler diets on the performance and some blood parameters. Italian Journal of Animal Science, 11(55), 298-302. 